\title{
On the dynamic integration of socialist core values and ideological and political education of college students
}

\author{
Yan Sun ${ }^{1,2}$, Maoling Liu ${ }^{1,2}$ \\ ${ }^{1}$ Chongqing Technology and Business Institute, Chongqing, 401520, China \\ ${ }^{2}$ Chongqing Radio \& TV University, 400039, China
}

Keywords: socialist core values; college students; ideological and political education

\begin{abstract}
The socialist core values as the inner core of the socialist core value system of our country, but also an important value basis guiding ideological and political education of contemporary college students. Today, the fundamental task of ideological and political education of college students involves to realize that dynamic integration of socialist core values and ideological and political education of college students, so that the core values can be fully integrated into all key aspects of ideological and political education among college students. This paper discusses the necessity of carrying out the socialist core values education for college students, and has proposed strategy selection of the dynamic integration of socialist core values and the ideological and political education of college students.
\end{abstract}

\section{Introduction}

Values can be said to be a measure of value inside, which governs the behavior, attitudes, information, and understanding, etc. of the entire human nature. Today, the moral status quo and causes of the college students urgently requires re-building the college students' ideology and morality. Socialist core values system as the inner spirit of socialism with Chinese characteristics system is a fundamental guarantee of moral reconstruction for college students. This value has been fully recognized by the people. We can learn from the past successful experiences, through the use of university ideological and political education to carry out the construction of socialist core values for college students. Socialist core value system as an important theory of our party is also the inherent requirement of the socialist system. Socialist value system occupies the command and dominance position among all socialist value targets. Socialist value system includes Marxism, socialism with Chinese characteristics, national spirit with patriotism as the center, socialist concept of honor and disgrace with reform and innovation as the center and other components, is dialectical unity of interpenetration and promotion. Values can be said that the key for college students to improve their personalities, and the lofty ideal is the important goals for them to yearn and pursuit, but also the spiritual power encouraging them to rise. Core values is the core concept occupying dominant position in society and plays a dominant role, and it is also the value principle which the current society should follow for a long-term, with a relatively more stable characteristic. College students, as the elite of citizens, but also the future hope of the nation, are an important force in the future construction and social development of the country. Educating and guiding their understanding and recognition of socialist core values, is a fundamental task of ideological and political education of college students

\section{The necessity of carrying out the socialist core values education for college students}

First, educate the college students to establish a scientific and reasonable value goal. Value goal mainly refers to the ultimate aim and objective of human values and moral awareness activities, which is also to figure out the question why you want to live and how to live. The selection value goal mainly refers to taking the understanding of interests as its basic premise, and the right value goal selection only be achieved through repeatedly ideological struggle in the social practice; while the lack of right value goal will certainly cause the body of values lose the right, rational behavior direction and lead to a way deviating from scientific values. For college students, in order to achieve the value target, it must be a long-standing process and it cannot be accomplished the whole 
task at one stroke, which requires ideological and political education work in colleges and universities should not do a crash job, but should implement subtly as much as possible. The process of college students moral education activities should be fully attached attention, continually innovate ways and means, so that moral education can have a more intense attraction to be more adapted to the growth law of contemporary college student talents.

Second, train young college students to achieve more important value identification. The so-called value identification mainly refers to the recognition and sharing on certain values which individual or the social community recognition uses interaction with each other, and it is also a kind of value orientation for people in their social lives, and showed the formation of common values. Although the vast majority of college students already have correct understanding for the socialist core values, and internalized it as their ideal values, but also a small number of college students are lack of identity for the socialist core values, or cannot balance it in all directions, gaining corresponding cognition and cannot realize the recognition of c the socialist core values under the condition that emotion and behavior is consistent. In view of this, we must use a variety of ways of education; in particular, to focus on the education of socialist core values, continuing to strengthen college students' recognition for the development of socialism with Chinese characteristics.

Third, encourage young college students to carry forward the noble value demands. The so-called value demands, mainly refers to the social orientation and life value orientation generated through the integration of social consciousness, which are the intrinsic motivation college students put into practice. Noble value demands should be the reasonable reflection of the noble aspirations of the world, life and values. With the example education in recent years, each university has propagandized a large number of typical moral models with noble aspirations. Based on promoting noble value demands, comprehensively propagandizing model figures in college students, and integrating into socialist core values, we can make the value of life of the students to be implemented, and thus be line with the requirements of the socialist core values, so it will not deviate from the right development prospects of life.

\section{Strategy selection of the dynamic integration of socialist core values and ideological and political education of college students}

The ideological and political education of contemporary college students under the new situation is based on the system with the socialist core values as the core, mainly including the Marxist theory education, the common ideal of socialism education, national spirit and the spirit of the times education as well as the education of socialism honor and shame, these contents above can be dynamically combined with college students' socialist core values.

\subsection{Practically guide college students' ideology through Marxist theory education}

The key point for implementing the Marxist theory education is to make the majority of college students have a profound understanding of Marxism as the unity of science and faith, the unity of truth and values, the unity of rules and norms, but also an important theory which is scientific and standardized and with truthfulness as well. It contains not only a very noble pursuit of value, but also shows a fair and just value judgment, and contains the value judgments of constant progress. The Marxism-Leninism theory education for college students can make students better establish the point of view of development, comprehensively understand Marxism-Leninism as the continued development science and voluntarily apply the basic principles of Marxism to guide the implementation of their own social practices; conduct Marxism-Leninism theory education to college students. Should help contemporary college students to fully understand the inevitability of combining Marxism and the realities of China, profoundly understand the theory achievements of Marxism-Leninism in the development of China, including Mao Zedong Thought, Deng Xiaoping Theory, "Three Represents", and scientific concept of development, which are all the products of the combination of Marxism-Leninism and the actual situation in China, is the new development of Marxism-Leninism in China and furthermore it is a scientific theory. To conduct Marxist-Leninist theory education to college students, should help them to establish a more firm belief in Marxism-Leninism, fully play the guiding role of Marxism and effectively lead the university 
students' ideology, to guide college students ideological and political education achieve sustainable development.

\subsection{Use the common ideal of socialism with Chinese characteristics education to comprehensively unite college students' will tendency}

The point of the education of common ideal of socialism with Chinese characteristics involves college students can accept our party's political ideas and political beliefs, and fully seen the consistency between the interests of the masses and their interests, so that ideal of construction of socialism with Chinese characteristics become a common ideal. Should comprehensively conduct education of common ideal of socialism with Chinese characteristics to college students, and effectively help college students recognize socialism with Chinese characteristics is the important requirement for our social development, should help college students to further strengthen the idea that it would be difficult to achieve the common ideal of the Chinese nation's great Chinese dream come true without the Party. Today, more and more students are very concerned about our party's policies and guidelines. On that account, the ideological and political education staff in colleges should through the implementation of national situation education and practical policy education, more effectively help the contemporary college students to deeper understand the principles and policies of the party and the country, and make college students more clearly aware of the problems among the socialist market economy with Chinese characteristics, to better attract the intelligence of college students talent among various center work of the Party and the country, unite college students' will and tendencies, practically form a good situation that all the people of one mind to create a truly great cause of socialism.

\subsection{Based on the education of national spirit and the spirit of the times, continue to improve struggling entrepreneurial spirit of college students}

The point of vigorously carrying forward national and time spirit education is to actively guide and cultivate college students talent to implement the spirit of the Chinese nation with patriotism as the core and the time spirit with comprehensive deepening reform as the core. Strengthen the national spirit education of college students, should fully cultivate national self-esteem and pride of college talents, making them to be able to achieve self-reliance, self-esteem and self-reliance, more fully apply the related publicity of the content of modern and contemporary Chinese history education and the achievement of China's modernization construction, effectively help college students to recognize the hardships of the roads of our revolution and construction, recognize the importance value of the Chinese nation indomitable spirit and the spirit of reform and innovation, thus guide the college students talent to establish the new idea that national interests above all else, actively promote college students talent clear their own social responsibility and historical mission, fully form sense of responsibility and accountability, and effectively identify individuals' reasonable position in the current society, establishing a correct socialist core values, and under the guidance of the right core values to become the builders and successors of the socialist cause with Chinese characteristics. College is an very important base to carry out the national spirit and the spirit of the times, should list the national spirit education with patriotism as the core and time spirit with deepen the reform as the core onto the key contents of ideological and political education of college student, effectively guide them to be the important disseminators and practitioners for national spirit and the spirit of the time, devote to improve their entrepreneurial spirit, and lay a solid foundation for advancing the socialist harmonious society.

\subsection{Carry out socialist concept of honor ideological and moral education to regulate the level of contemporary college students}

The key point for implementing Socialist Concept of Honor and Disgrace is to fully help contemporary college students combine individual behavior with social ethics, so let them be able to learn to behave. The various issues existing in contemporary college students' moral and values development have resulted in the emergence of phenomenon in contemporary college students, such as fail to distinguish right from wrong, fail to distinguish good from evil, beauty and ugliness bound confusing, and honor and disgrace idea blurred even inversion. Some college students have high political enthusiasm on the surface, but take politics lightly at behind. So we can see that, there is 
extremely complex motivation behind the positive demand for progress, and in the back of comprehensive study, there are tendencies of individual utilitarian, which, in terms of ideological and political education, exists emotions of conflict to some extent. The ideological and political education staff in colleges must be based on the implementation of Socialist Concept of Honor and Disgrace education, which acts on the whole process of the formation and cultivation of values for college students, and taking it as a moral benchmark to effectively regulate and restrain the daily thought and specific actions of college students. In the society of socialist with Chinese characteristics, the distinction between right and wrong, distinction between good and evil, distinction between beauty and ugliness must not be confused, what to adhere and what to oppose, what to advocate and what to resist, should be sure to do it unequivocally. In other words, only distinguish honor and disgrace, discern between good and evil, beauty and ugliness, so that college students can form a correct value judgment, to make the current society really form an excellent moral fashion. We can say that Eight Dos and Don'ts provides the most basic value orientation as well as the code of conduct for the ideological and moral qualities of college students from positive and negative two different aspects thereby better regulate the ideological and moral quality of college students, thus guide the college students talent clear the distinction between honor and shame, can practically do know the glory and courage, sense of shame and to avoid, thus promote the college students to form of active struggling particularly great intrinsic momentum for development.

\section{Conclusion}

In summary, the use of socialist core values to implement the ideological and political education of college students is the key point of the full realization of college ideological and political education innovation. It is clear that colleges and universities should become important place for the socialist core values education. Realization of dynamic integration of socialist values and ideological and political education of college students is to integrate socialist values into innovation practically, and let the core values of the basic requirements can be effectively implemented and fully reflected, so as to provide a solid foundation for the harmonious development of ideological and political education of young college students. It should be fully highlight the party's leadership to improve political literacy of college students, help college students better understand the superiority of the socialist system, effectively straighten their positions and establish lofty ideals of socialism, strengthen their own sense of responsibility to serve the country, lead the new trend of social development, and contribute their youth and wisdom to comprehensively deepen reforms and realize Chinese dream.

\section{References}

[1]Yang Wenjing. Analysis on the Ideological and Political Education in colleges under the vision of Socialist Core Values [J], CPC Taiyuan Municipal Party College Journal, 2013 (1).

[2] Zhang Aixiao. Socialist core values guide the ideological and political education of college students [J]. Economist, 2013 (5).

[3] Su Ming. Use socialist core values to lead the ideological and political education [J]. Modern Enterprise, 2013 (10)

[4] Sa Qier. Taking the socialist core values as guidance, continue to explore new way of ideological and political education for college students [J]. Inner Mongolia publicity and ideological work, 2014 (5).

[5] Wang Jian. Strategy research on the integration of socialist core values into ideological and political education. [J] Intelligence, 2014 (19) 